\title{
Molecular diagnosis of Anaplasma marginale in cattle: quantitative evaluation of a real-time PCR (Polymerase Chain Reaction) based on $m s p 5$ gene $^{1}$
}

\author{
Gisele M. Bacanelli² ${ }^{2}$ Carlos A.N. Ramos ${ }^{3}$ and Flábio R. Araújo ${ }^{4^{*}}$
}

\begin{abstract}
Bacanelli G.M., Ramos C.A.N. \& Araújo F.R. 2014. Molecular diagnosis of Anaplasma marginale in cattle: quantitative evaluation of a real-time PCR (Polymerase Chain Reaction) based on msp5 gene. Pesquisa Veterinária Brasileira 34(1):29-33. Embrapa Gado de Corte, Avenida Rádio Maia 830, Campo Grande, MS 79106-550, Brazil. E-mail: flabio.araujo@embrapa.br

The rickettsia Anaplasma marginale is considered the main agent of bovine anaplasmosis. Due the nonspecific clinical signs of the anaplasmosis, the diagnosis of infection depends of laboratory confirmation. In recent years, molecular diagnostic methods have been used to detect $A$. marginale in cattle. However, the existence of a large number of assays of different sensitivity and cost makes the choice of an appropriate test difficult. In the present study, a real-time Polymerase Chain Reaction (PCR) based on the $m s p 5$ target gene was quantitatively assessed and compared to an end point PCR. Both reactions were subjected to sensitivity and specificity evaluation using plasmid DNA and samples from cattle experimentally infected with $A$. marginale. A comparative field trial of the tests was carried out using samples of cattle from a stable enzootic area for $A$. marginale. The real-time PCR showed a higher sensitivity than the end point PCR. This reaction (i.e. real-time PCR) was able to detect one copy of the $m s p 5$ gene in $100 \eta \mathrm{\eta}$ of plasmidial DNA, and more than $80 \%$ of its results were positive among experimentally infected animals seven days after infection. In addition, based on in silico analysis, the real-time PCR evaluated in the present study appears to be useful for the detection of A. ovis.
\end{abstract}

INDEX TERMS: Real-time PCR, diagnosis, Anaplasma marginale, msp5, cattle.

RESUMO.- [Diagnóstico molecular de Anaplasma marginale em bovinos: avaliação quantitativa de uma PCR em tempo real baseada no gene $m s p 5$.] A riquétsia Anaplasma marginale é considerada o principal agente da anaplasmose bovina. Devido a não especificidade dos sinais clínicos, a confirmação da infecção nos animais depende de testes laboratoriais. Recentemente, métodos de diagnóstico molecular têm sido aplicados para detecção de $A$. marginale em bovinos. No entanto, a grande quantidade de testes com diferentes sensibilidade e custos tem dificultado a escolha do ensaio mais adequado. No presente

\footnotetext{
${ }^{1}$ Received on September 16, 2013.

Accepted for publication on November 11, 2013.

${ }^{2}$ Programa de Pós Graduação em Ciência Animal, Universidade Federal de Mato Grosso do Sul (UFMS), Av. Felinto Müller s/n, Cidade Universitária, Campo Grande, MS 79070-900, Brazil.

${ }^{3}$ Embrapa Gado de Corte, Av. Rádio Maia 830, Campo Grande, MS 79106550, Brazil. Bolsista DTI Funape/Embrapa.

${ }^{4}$ Embrapa Gado de Corte, Av. Rádio Maia 830, Campo Grande, MS. *Corresponding author: flabio.araujo@embrapa.br
}

estudo, uma PCR em tempo real baseada no gene $m s p 5$ foi avaliada quantitativamente e comparada a uma reação de PCR convencional. As reações foram submetidas à avaliação de sensibilidade e especificidade com DNA plasmidial e amostras provenientes de bovinos experimentalmente infectados por A. marginale. Uma avaliação comparativa a campo foi realizada entre os testes utilizando amostras provenientes de bovinos criados em uma região de estabilidade enzoótica para A. marginale. Embora os testes não tenham apresentado diferença estatisticamente significativa, a PCR em tempo real apresentou valor de sensibilidade maior do que a PCR convencional. A PCR em tempo real foi capaz de detectar uma cópia de msp5 em 100ng de DNA plasmidial, e mais de $80 \%$ de resultados positivos entre bovinos experimentalmente infectados apenas sete dias após infecção. Além disso, baseado em análise in silico, a PCR em tempo real avaliada aqui pode ser útil para detecção de Anaplasma ovis.

TERMOS DE INDEXAÇÃO: PCR em tempo real, diagnóstico, Anaplasma marginale, msp5, bovinos. 


\section{INTRODUCTION}

Anaplasma marginale is an obligate intracellular pathogen belonging to the genus Anaplasma (Order Rickettsiales, Family Anaplasmataceae) which causes anaplasmosis in bovines (Theiler 1910, Dumler et al. 2001, Kocan et al. 2003). This rickettsia is transmitted biologically by ixodid ticks. The species Rhipicephalus (Boophilus) microplus is the only biological vector that has been identified in Brazil (Kessler \& Schenk 1998). The clinical presentation of anaplasmosis is nonspecific and can include fever, anemia, jaundice, anorexia, weight loss and death in susceptible cattle (Zaugg 1985).

Because of the difficulty of diagnosing $A$. marginale infection by clinical means, several laboratorial techniques have been used to detect this rickettsia in cattle. In the acute phase of the disease, when rickettsemia is high, initial bodies are easily detected in bovine erythrocytes by microscopy of stained blood smears (Farias 1995). However, the rickettsemia of chronically infected animals is generally low, hindering its diagnosis (Palmer et al. 1986). In this context, molecular diagnostic assays such as PCR have been developed and are both highly sensitive and specific (Palmer et al. 1986, Gale et al. 1996, Corona et al. 2000).

Recently, several types of polymerase chain reactions (PCR) such as nested PCR, multiplex PCR, real-time PCR) have been developed and used for the diagnosis of various pathogens (Courtney et al. 2004, Carelli et al. 2007). Real-time PCR has a number of advantages, including high sensitivity and specificity, usefulness as a quantitative assay, and is able to deliver faster results than end point PCR (Bell \& Ranford-Cartwrightet 2002). However, there are few studies of paired comparisons between real-time and end point PCR, making the choice of PCR technique difficult. Therefore, the aim of this study was to quantitatively assess a real-time PCR assay and compare it with an end point PCR based on the same target gene ( $m s p 5$ ).

\section{MATERIALS AND METHODS}

Samples. Blood DNA samples $(n=48)$ from six Aberdeen Angus cattle experimentally infected with a Brazilian isolate of Anaplasma marginale were used. These cattle, used in a previous study by Araújo (2005), were kept in an isolation area of the Embrapa Beef Cattle farm, Campo Grande, MS, Brazil. Sampling was performed at $0,5,7,9,16,26,33$ and 140 days post-inoculation (DPI). Blood samples $(\mathrm{n}=99)$ from a herd kept in an area of enzootic stability for A. marginale (Embrapa Gado de Leite, Juiz de Fora, MG, Brazil) were also used.

DNA extraction. DNA extractions were taken from $350 \mu \mathrm{L}$ of bovine blood, using the Easy DNA kit (Invitrogen ${ }^{5}$ ), following the manufacturer's instructions. The integrity and concentration of DNA samples were assessed by agarose gel electrophoresis $0.8 \%$ and spectrophotometry in NanoDrop ND1000 (Thermo Scientific $^{6}$ ).

Real-time PCR. Real-time PCR was performed with Platinum SYBR Green/ROX (Invitrogen ${ }^{5}$ ) in a final volume of $12.5 \mu \mathrm{L}$, using the previously described (Picoloto et al., 2010) primer set msp5 AMTR F: 5' AAGGCGAGGAGCTGTTTAAG 3' and AMTR R: 5' CTACTGCCTCACAAGGACGA 3'. Amplification was performed with a StepOne Plus thermocycler (Applied Biosystems ${ }^{7}$ ) as follows: $50^{\circ} \mathrm{C}$ for 2 minutes, $95^{\circ} \mathrm{C}$ for 2 minutes, 40 cycles at $95^{\circ} \mathrm{C}$ for 30 seconds (denaturation) and $54^{\circ} \mathrm{C}$ for 15 seconds (annealing/extension). A

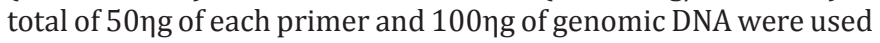
in each PCR. Samples were considered positive when the amplification curves exceeded the cutline automatically proposed by the Step0ne Software v2.11, and showed a dissociation curve (melt curve) similar to the positive control $\left( \pm 0.5^{\circ} \mathrm{C}\right)$.

To check the presence of PCR inhibitors in the extracted DNA samples, a real-time PCR was performed for the bovine constitutive gene glyceraldehyde-3-phosphate dehydrogenase (GAPDH) using the primers gadphF 5'GGCGTGAACCACGAGAAGTATAA 3' and gadphR 5'CCCTCCACGATGCCAAAGT 3', and the reaction described by Robinson et al. (2007).

End point PCR. The end point PCR was performed using the primers $m s p 5$ F 5'ATGAGAATTTTCAAGATTGTGTCTAACCTT 3' and msp5R 5' AGGAAAGCCCCCAAAGCCCCATACTT 3', which delimit all msp5 genes of $A$. marginale, and a 3' untranslated region, according to Silva et al. (2006), resulting in an amplicon of $714 \mathrm{bp}$. Amplification conditions were: $94^{\circ} \mathrm{C}$ for 4 minutes, followed by 35 cycles at $94^{\circ} \mathrm{C}$ for 1 minute, $60^{\circ} \mathrm{C}$ for 30 seconds and $72^{\circ} \mathrm{C}$ for 45 seconds. A final extension step at $72{ }^{\circ} \mathrm{C}$ for 4 minutes was used. The results of PCR were analyzed in 1\% agarose gel stained with Sybr Gold (Invitrogen ${ }^{5}$ ). Samples were considered positive when amplification of a fragment corresponding to the expected amplicon size (714 bp) was visualized under ultraviolet light.

Evaluation of sensitivity. To evaluate the sensitivity of both assays (end point and real-time PCR), the $m s p 5$ gene was cloned into the plasmid pTrCHis TOPO (Invitrogen ${ }^{5}$ ), and the recombinant plasmid ( $\mathrm{p}$ TrcHis TOPO/msp5) was propagated in Escherichia coli TOP10. After plasmid purification using Wizard Plus minipreps kit $\left(\right.$ Promega $^{8}$ ), plasmidial DNA concentration was quantified by spectrophotometry in Nanodrop ND1000. The number of DNA copies was estimated as described by Ke et al. (2006), and DNA was diluted serially $\left(10^{8}\right.$ to $10^{0}$ copies $\left./ \mathrm{ml}\right)$ in nuclease-free water. The dilutions were subjected to both PCR reactions, as described above.

Clinical sensitivity was evaluated using 48 blood samples from six experimentally infected Aberdeen Angus cattle. The samples collected at $0,5,7,9,16,26,33$ and 140 DPI were also subjected to both reactions.

Evaluation of specificity. To evaluate specificity a sample of DNA from Babesia bovis, and another from Babesia bigemina from blood of experimentally infected cattle were tested. In addition, an in silico analysis of specificity was performed with primer sequences used in the real-time PCR using the ClustalW algorithm (www.ebi.ac.uk/Tools/clustalw2/index.html) and the blastn online tool.

Field trial.The field evaluation of PCR reactions was carried out using 99 blood samples from cattle raised in an area of enzootic stability for $A$. marginale.

Statistical analysis. The significance of the differences between the frequencies of positive results obtained in the tests was measured by Fisher's exact test. The agreement between the tests was expressed using the kappa index as described by Kramer and Feinstein (1981). Analysis was performed with the aid of Bioestat 5.0 (Ayres et al. 2007) software.

\footnotetext{
${ }^{5}$ Invitrogen - Life Technologies Corporations, 3175 Staley Road, Grand Island, New York, USA.

${ }^{6}$ Thermo Fisher Scientific, 81 Wyman Street, Waltham, Massachusetts, USA.

${ }^{7}$ Applied Biosystmes - Life Technologies Corporations, 3175 Staley Road, Grand Island, New York, USA.

${ }^{8}$ Promega Corporation, 2800 Woods Hollow Road, Madison, Wisconsin, USA.
} 


\section{RESULTS}

The real-time PCR evaluated in the present study was able

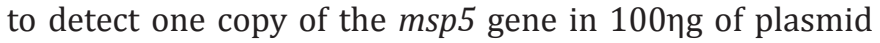
DNA (Fig.1A), whereas conventional PCR detected up to 1000 copies. The standard curve obtained from the dilutions of the plasmid DNA showed an inversely proportional linear response between the DNA concentration and the
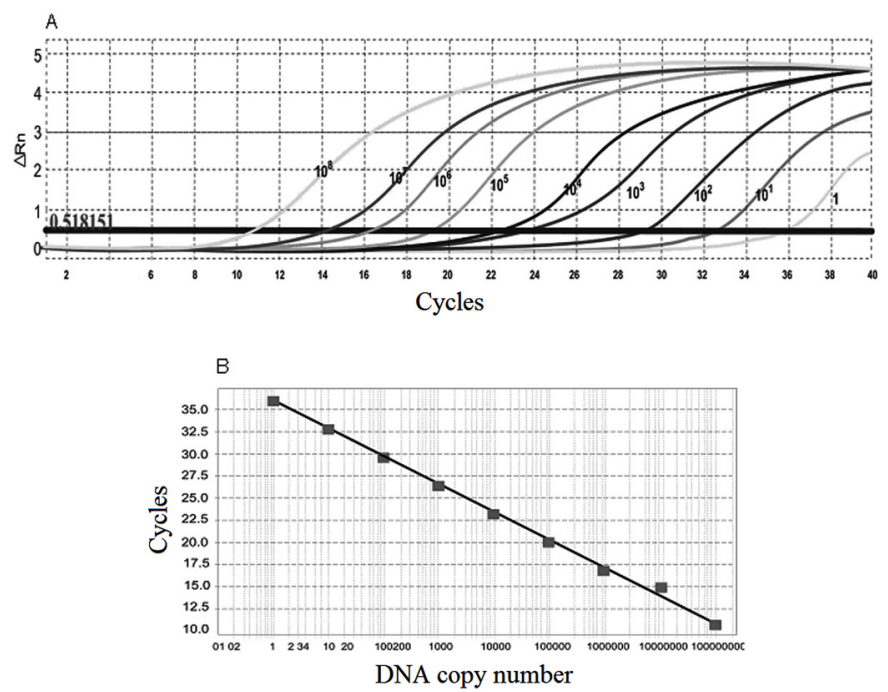

Fig.1. Sensitivity analysis of real-time PCR for the msp5 gene of Anaplasma marginale. (A) Amplification plot. (B) Standard curve obtained in real-time PCR using serial dilutions of msp $5 /$ pTrcHis-TOPO $\left(10^{8}-10^{0}\right.$ copy of the plasmid DNA). number of real-time PCR cycles in the $10^{8}-10^{\circ}$ copy range, with values of $\mathrm{R}^{2}=0.998$, and amplification efficiency of 107\% (Fig.1B). The melt temperature of the amplicon generated in this assay was $81.19 \pm 0.26^{\circ} \mathrm{C}$.

No unspecific amplification was detected in $m s p 5$ with real-time PCR and end point PCR when DNA from Babesia bovis or B. bigemina was used as a template. In silico analysis using isolate of Anaplasma marginale as a reference (Florida, Genbank CP001079), demonstrated that the primers are specific for $A$. marginale and $A$. ovis, showing $100 \%$ identity only among isolates of these species (Fig.2).

In the analysis of DNA samples from cattle experimentally infected with A. marginale (at 0, 5, 7, 9, 16, 26, 33 and 140 DPI), the real-time PCR was able to detect five positive animals $(83.3 \%)$ on the seventh day post-inoculation, while the end point PCR detected as positive only one animal (16.7\%). At 9 DPI, all six cattle were detected as positive (100\%) with real-time PCR, and only three (50\%) with end point PCR. From 16 DPI to 140 DPI, all animals were found to be positive using both reactions (Table 1).

The overall frequency of infection by $A$. marginale in cattle from the region of Juiz de Fora, MG, Brazil was 92.92\% (92/99) with real-time PCR, and 87.87\% (87/99) with PCR (Table 2). No significant difference was observed between tests $(\mathrm{p}=0.062)$, with a level of agreement of $94.9 \%$ (kappa index $=0.87$ ). The feasibility of all DNA samples was confirmed by real-time PCR for the constitutive GAPDH bovine gene.

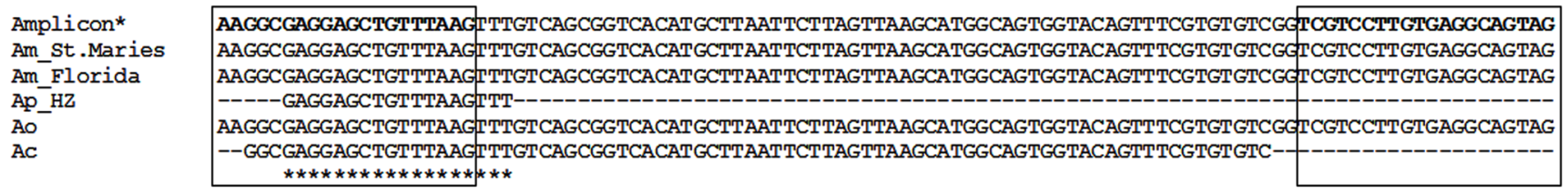

*Based on the genome of Anaplasma marginale Florida CP001079: Am = Anaplasma marginale; Ap = Anaplasma phagocytophilum; Ao = Anaplasma ovis; Ac = Anaplasma centrale.

Fig.2. Multiple alignment of the amplicon sequences generated by real-time PCR for msp5 gene of Anaplasma marginale (St. Maries and Florida, Genbank CP000030 and CP001079, respectively) and homologous sequences of Anaplasma phagocytophilum (Genbank CP000235), Anaplasma ovis (Genbank HM195102) and Anaplasma centrale (Genbank CP001759). Annealing sites of primers highlighted.

Table 1. End point PCR and real-time PCR based on msp5 gene of Anaplasma marginale using DNA samples of experimentally infected

\begin{tabular}{|c|c|c|c|c|c|c|c|c|c|}
\hline \multirow[t]{2}{*}{ Animal } & \multirow[t]{2}{*}{ PCR } & \multicolumn{8}{|c|}{ Days post-inoculation (DPI) } \\
\hline & & 0 & 5 & 7 & 9 & 16 & 26 & 33 & 140 \\
\hline \multirow[t]{2}{*}{1} & End point PCR & - & - & - & + & + & + & + & + \\
\hline & real-time PCR & - & - & - & + & + & + & + & + \\
\hline \multirow[t]{2}{*}{2} & End point PCR & - & - & - & + & + & + & + & + \\
\hline & real-time PCR & - & - & + & + & + & + & + & + \\
\hline \multirow[t]{2}{*}{967} & End point PCR & - & - & - & - & + & + & + & + \\
\hline & real-time PCR & - & - & + & + & + & + & + & + \\
\hline \multirow[t]{2}{*}{970} & End point PCR & - & - & - & - & + & + & + & + \\
\hline & real-time PCR & - & - & + & + & + & + & + & + \\
\hline \multirow[t]{2}{*}{975} & End point PCR & - & - & - & - & + & + & + & + \\
\hline & real-time PCR & - & - & + & + & + & + & + & + \\
\hline \multirow[t]{2}{*}{982} & End point PCR & - & - & + & + & + & + & + & + \\
\hline & real-time PCR & - & - & + & + & + & + & + & + \\
\hline
\end{tabular}

$\overline{+ \text { Positive result, }}$ - negative result.
Table 2. Comparison of end point PCR and real-time PCR for the msp5 gene of Anaplasma marginale in a herd of cattle from area of enzootic stability

\begin{tabular}{lccc}
\hline \multirow{2}{*}{ End point PCR } & \multicolumn{2}{c}{ Real-time PCR } & \multirow{2}{*}{ Total } \\
\cline { 2 - 3 } & Positive & Negative & \\
\hline Positive & 87 & 0 & 87 \\
Negative & 5 & 7 & 12 \\
TOTAL & 92 & 7 & 99
\end{tabular}

\section{DISCUSSION}

The real-time PCR evaluated in the present study was 1000 times more sensitive than the end point PCR when plasmidial DNA was used as template. The higher sensitivity of real-time PCR was also evident with the samples of experimentally infected cattle, since, on the seventh DPI, real-time PCR detected a greater number of positive animals (83.3\%) than end point PCR (16.7\%). However, when the two re- 
actions were subjected to a comparative field trial using samples from animals from an enzootic stability region, a significant difference was not observed. Previously described real-time PCR assays for the detection of Anaplasma marginale have also shown high levels of sensitivity, as well as those reported by Carelli et al. (2007) and Decaro et al. (2008) (detection limit $=5$ copies of DNA). However, in both cases a hydrolysis probe based system was used (TaqMan system), whereas in the present stud the SYBR Green system was used. Despite having some advantages, mainly related to specificity, the TaqMan system is more expensive than the Sybr Green system. Considering only the cost of reagents, the cost of a real-time PCR reaction based on hydrolysis probes is approximately $25 \%$ higher in Brazil than a reaction based on Sybr Green. Both real-time PCR systems are at least $50 \%$ more expensive than end point PCR.

There are less expensive alternatives for the diagnosis of chronic infection by $A$. marginale, such as serological tests (ELISA, IFAT). However, these are not able to reveal the exact profile of prevalence of infection at a particular point, as detectable levels of antibodies may remain in the animal for long periods, even after elimination of the infectious agent. Molecular techniques, meanwhile, detect the infectious agent but not the byproducts of infection. Recently, discrepancies among $A$. marginale prevalence rates ( $87.5 \%$ with ELISA and $56.9 \%$ with real-time PCR) were reported in cattle from Puntarenas Province, Costa Rica (Shebish et al. 2012).

A nested highly sensitive (detection limit $=2$ copies) PCR based on msp5 of $A$. marginale has been described (Ybanez et al. 2013). However, this reaction is carried out in two steps, while real-time PCR is performed in a single step. Furthermore, real-time PCR is widely accepted as a useful quantitative technique for studies of vaccine evaluation, drugs, vector competence, and other studies.

The primers used in real-time PCR were designed to amplify a fragment of $104 \mathrm{bp}$ between the end of msp5 gene and the $5^{\prime}$ untranslated region, and between the msp 5 and pstS gene of A. marginale. Although, other species of Anaplasma were not evaluated in this study, in silico analysis using isolate of $A$. marginale (Florida, Genbank CP001079) as a reference, demonstrated that the primers are specific for A. marginale and A. ovis, showing $100 \%$ identity only among isolates of these species. The lack of homology between the sequences analyzed suggests that the test did not amplify DNA from $A$. centrale and A. phagocytophilum. However, this reaction has not been tested experimentally. Although the primers evaluated in this study exhibited total complementarity with $A$. ovis, based on in silico analysis, this species has not been reported in Brazil and its importance as an infectious agent for cattle is still unknown. However, recent reports provide evidence of the possibility of $A$. ovis infection in cattle (Hornok et al. 2010, Hornok et al. 2012).

The overall frequency of infection by A. marginale in cattle from the region of Juiz de Fora, MG, Brazil was $92.92 \%$ (92/99) with real-time PCR, and 87.87\% (87/99) with PCR. These results suggest that the region is in enzootically stable for $A$. marginale, confirming the results reported by Carvalho et al. (2012). There was no significant difference between the tests $(\mathrm{p}=0.062)$, with a level of agreement of 94.9\% (kappa index $=0.87$ ). Considering the discordant results, five samples (5.1\%) were positive in real-time PCR and negative in the end point PCR (Table 2). False negative results in PCR may occur due to the presence of inhibitors resulting from the process of DNA extraction (Tondella et al. 2002). However, in the present study, the feasibility of all DNA samples was confirmed by real-time PCR for the constitutive GAPDH bovine gene. Therefore, the different frequencies detected by the assays are due to the higher sensitivity of real-time PCR.

Although significant difference between real-time PCR and end point PCR was not observed in field evaluation, the use of real-time PCR is indicated as a quantitative technique when rickettsial loads need to be measured (Lohr et al. 2002, Futse et al. 2003). On the other hand, due its relatively lower cost, end point PCR is a more suitable tool for epidemiological studies. However, the high sensitivity of real-time PCR may also be exploited in epidemiological studies, especially in wild ruminants, which usually present chronic infections with low levels of rickettsemia (Picoloto et al. 2010), and are susceptible to infection by both A. marginale and A. ovis.

\section{REFERENCES}

Araújo F.R. 2005. Avaliação das proteínas recombinantes MSP1a e MSP2 de Anaplasma marginale, associadas a oligonucleotídeo CPG 2006 como adjuvante, como imunógenos contra a anaplasmose bovina. Tese de Doutorado, Universidade Federal da Bahia, Salvador.

Ayres M., Ayres J.R.M., Ayres D.L. \& Santos A.S. 2007. BioEstat 5.0-Aplicações Estatísticas nas Áreas das Ciências Biológicas e Médicas: Sociedade Civil Mamirauá, Belém. CNPq, Brasília. 290p.

Bell A.S. \& Ranford-Cartwright L.C. 2002. Real-time quantitative PCR in parasitology. Trends Parasitol. 18:337-342.

Carelli G., Decaro N., Lorusso A., Elia G., Lorusso E., Mari V., Ceci L. \& Buonavoglia C. 2007. Detection and quantification of Anaplasma marginale DNA in blood samples of cattle by real-time PCR. Vet. Microbiol. 124:107-114.

Carvalho A.H.O., Silva Junior F.A., Daher D.O., Rocha C.M.B.M. \& Guimarães A.M. 2012. Effect of milk production system on the enzootic stability to Anaplasma marginale and Babesia bovis in calves in the Campo das Vertentes region of Minas Gerais state, Brazil. Semina: Ciênc. Agrárias 33:323-332.

Corona B., Mazorra L.M., Blandino T. \& Martínez S. 2000. Detección de Anaplasma marginale mediante amplificación del gen msp5. Revta Sal. Animal 22:168-173.

Courtney J.W., Kostelnik L.M., Zeidner N.V. \& Massung R.F. 2004. Multiplex Real-Time PCR for detection of Anaplasma phagocytophilum and Borrelia burgdorferi. J. Clin. Microbiol. 42:3164-168.

Decaro N., Carelli G., Lorusso E., Lucente M.S., Greco G., Lorusso A., Radogna A., Ceci L. \& Buonavoglia C. 2008. Duplex real-time polymerase chain reaction for simultaneous detection and quantification of Anaplasma marginale and Anaplasma central. J. Vet. Diagn. Invest. 20:606-611.

Dumler J., Barbet A., Bekker C., Dasch G., Palmer G., Ray S., Rikihisa Y. \& Rurangirwa F. 2001. Reorganization of genera in the families Rickettsiaceae and Anaplasmataceae in the order Rickettsiales: unification of some species of Ehrlichia with Anaplasma, Cowdria with Ehrlichia and Ehrlichia with Neorickettsia, descriptions of six new species combinations and designation of Ehrlichia equi and 'HE agent' as subjective synonyms of Ehrlichia phagocytophila. Int. J. Syst. Evol. Microbiol. 51:2145-2165.

Farias N.A.R. 1995. Diagnóstico e Controle da Tristeza Parasitária Bovina. Editora Agropecuária Guaíba, Porto Alegre. 
Futse J.E., Ueti M.W., Knowles D.P. Jr \& Palmer G.H. 2003. Transmission of Anaplasma marginale by Boophilus microplus: Retention of vector competence in the absence of vector-pathogen interaction. J. Clin. Microbiol. 41:3829-3834.

Gale K.R., Dimmock C.M., Gartside M. \& Leatch G. 1996. Anaplasma marginale: detection of carrier cattle by PCR-ELISA. Int. J. Parasitol. 26:11031109.

Hornok S., Hofmann-Lehmann R., Fernández de Mera I.G., Meli M.L., Elek V., Hajtós I., Répási A., Gönczi E., Tánczos B., Farkas R., Lutz H. \& De la Fuente J. 2010. Survey on blood-sucking lice (Phthiraptera: Anoplura) of ruminants and pigs with molecular detection of Anaplasma and Rickettsia spp. Vet. Parasitol. 174:355-358.

Hornok S., Micsutka A., Fernández de Mera I.G., Meli M.L., Gönczi E., Tánczos B., Mangold A.J., Farkas R., Lutz H., Hofmann-Lehmann R. \& De la Fuente J. 2012. Fatal bovine anaplasmosis in a herd with new genotypes of Anaplasma marginale, A. ovis and concurrent haemoplasmosis. Res. Vet. Sci. 92:30-35.

Ke G.M., Cheng H.L., Ke L.Y., Ji W.T., Chulu J.L., Liao M.H., Chang T.J. \& Liu H.J. 2006. Development of a quantitative light cycler real-time RT-PCR for detection of avian reovirus. J. Virol. Meth. 133:6-13.

Kessler R.H. \& Schenk M.A.M. 1998. Carrapato, Tristeza Parasitária e Tripanossomose dos Bovinos. Embrapa Gado de Corte, Campo Grande, MS.

Kocan K.M., Fuente J., Guglielmone A.A. \& Melendez R.D. 2003. Antigens and alternatives for control of Anaplasma marginale infection in cattle. Clin. Microbiol. Rev. 16:698-712.

Kramer M.S. \& Feinstein A.R. 1981. Clinical biostatistics. LIV. The biostatistics of concordance. Clin. Pharmacol. Ther. 29:111-123.

Lohr C.V., Rurangirwa F.R., McElwain T.F., Stiller D. \& Palmer G.H. 2002. Specific expression of Anaplasma marginale major surface protein 2 salivary gland variants occurs in the midgut and is an early event during tick transmission. Infect. Immun. 70:14-120.

Palmer G.H., Barbet A.F., Kuttler K.L. \& McGuire T.C. 1986. Detection of an
Anaplasma marginale common surface protein present in all stages of infection. J. Clin. Microbiol. 23:1078-1083.

Picoloto G., Lima R.F., Olegário L.A.O., Carvalho C.M.E., Lacerda A.C.R., Tomás W.M., Borges P.A.L., Pellegrin A.O. \& Madruga C.R. 2010. Real-time polymerase chain reaction to diagnose Anaplasma marginale in cattle and deer (Ozotoceros bezoarticus leucogaster) of the Brazilian Pantanal. Revta Bras. Parasitol. Vet. 19:186-188.

Robinson T.L., Sutherland I.A. \& Sutherland J. 2007. Validation of candidate bovine reference genes for use with real-time PCR. Vet. Immun. Immunopathol. 115:160-165.

Silva V.M.G., Araújo F.R., Madruga C.R., Soares C.O., Kessler R.H., Almeida M.A.O., Fragoso S.P., Santos L.R., Ramos C.A.N., Bacanelli G. \& Torres Júnior R.A.A. 2006. Comparison between indirect enzyme-linked immunosorbent assays for Anaplasma marginale antibodies with recombinant major surface protein 5 and initial body antigens. Mem. Inst. Oswaldo Cruz 101:511-516.

Shebish E., Vemulapalli R. \& Oset C. 2012. Prevalence and molecular detection of Anaplasma marginale, Babesia bovis and Babesia bigemina in cattle from Puntarenas Province, Costa Rica. Vet. Parasitol. 188:164-167.

Theiler A. 1910. Anaplasma marginale (gen. spec. nov.): the marginale points in the blood of cattle suffering from a specific disease. In: Theiler A. (Ed.), Report of the Government Veterinary Bacteriologist, in Transvaal. Department of Agriculture, p.1908-1909.

Tondella M.L., Talkington D.F., Holloway B.P., Dowell S.F., Cowley K., Soriano-Gabarro M., Elkind M.S. \& Fields B.S. 2002. Development and evaluation of real-time PCR-based fluorescence assays for detection of Chlamydia pneumoniae. J. Clin. Microbiol. 40:575-583.

Ybañez A.P., Sivakumar T., Battsetseg B., Battur B., Altangerel K., Matsumoto K., Yokoyama N. \& Inokuma H 2013. Specific molecular detection and characterization of Anaplasma marginale in Mongolian cattle. J. Vet. Med. Sci. 75:399-406.

Zaugg J.L. 1985. Bovine anaplasmosis: transplacental transmission as it relates to stage of gestation. Am. J. Vet. Res. 46:570-572. 